Available online at GSC Online Press Directory

GSC Biological and Pharmaceutical Sciences

e-ISSN: 2581-3250, CODEN (USA): GBPSC2

(RESEARCH ARTICLE)

\title{
Gas chromatography and mass spectroscopy analysis and phytochemical characterization of Aegle marmelos (Bael) leaf, Stem and its screening of antimicrobial activity
}

Sahu Ajay Kumar 1, *, Kar Barsha Rani 2, Deepthi Kiran 1, ${ }^{*}$, Pallath S. Karthika ${ }^{3}$, Dakni Simran J 4, Samal Pinki 5, Niharika Nagilla S ${ }^{4}$, Swetha T ${ }^{1}$, Sneha T ${ }^{1}$, A. Anthony Surya Prakash ${ }^{1}$ and H.G Varshini Raju ${ }^{1}$

${ }^{1}$ Department of Microbiology, Bangalore University, Bangalore, India.

${ }^{2}$ Department of Biotechnology, AMIT College, Utkal University, Bhubaneswar, Odisha, India.

${ }^{3}$ Department of Bioscience, Mahatma Gandhi University, India.

${ }^{4}$ Department of Biotechnology, Bangalore University, Bangalore, India.

Publication history: Received on 21 August 2019; revised on 17 September 2019; accepted on 20 September 2019

Article DOI: https://doi.org/10.30574/gscbps.2019.8.3.0159

\begin{abstract}
Phytochemical screening tests was conducted for five plant species and found that extract contains a variety of Phytochemical like saponins, tannins, flavonoids, terpenoids, glycosides and reducing sugars and among which there is higher level of precipitation for phenol and flavonoids. As they are essential source of antimicrobial agents against pathogen, their extract were tested for its antimicrobial activity by well diffusion method using Nutrient agar against human pathogenic bacteria like Staphylococcus aureus, Escherichia coli. This study provided evidence to confirm the presence of various medicinally important bioactive compounds or Phytochemical that has got biological importance and it justifies their use in the traditional medicines for the treatment of different diseases and this findings suggest that the selected plant extracts possesses antimicrobial properties that could be used for biological control of bacterial cultures and this bioactive compounds serve as a source of antimicrobial agents against human pathogens. Medicinal plants have bioactive compounds which are used for curing of various human diseases and also play an important role in healing. Phytochemical have two categories i.e., primary and secondary constituent. The phytochemical analysis of the plants is very important commercially and has great interest in pharmaceutical companies for the production of the new drugs for curing of various diseases. this GC-MS has been used as standard protocol for a foreign substance identification because of its used to identify the particular specific test results which is indicates or identifies the presences of that particular substance. The aqueous leaf extract were used for to identify and the phytochemical analysis used to find out the phytochemical constituents presents at the taken plants. Plant showed that the alkaloids, trepenoids, phenol and tannins, reducing sugar, saponin, proteins, anthocyanin, coumarin and glycosides were found to be presents in the given plants. Gas chromatography with mass spectroscopy detection is the state of the art methods for detection and identification of unknown compound, it is also not infallible and many compounds are difficulty with their accuracy certainty.
\end{abstract}

Keywords: Gas chromatography and mass spectroscopy; Phytochemical analysis; Aegle marmelos leaf; Antimicrobial activity

\section{Introduction}

Gas Chromatography-Mass Spectrometry (GC-MS) is a hyphenated analytical technique that combines the separation properties of gas-liquid chromatography with the detection feature of mass spectrometry to identify different substances; GC is used to separate the volatile and thermally stable substitutes in a sample whereas GC-MS fragments

\footnotetext{
${ }^{*}$ Corresponding author

E-mail address: Sahu88506@gmail.com
} 
the analyte to be identified on the basis of its mass [1]. The GC-MS included include drugs detection, fire investigation and identification of unknown samples, including that of materials sample obtained from planet mars during probe mission early. There are other applications which include the environment cleanup; GC-MS is also analysis the particles from a human body order to help link a criminal to crime. Law enforcement is used for detection of illegal narcotics and drug sniffing dogs. Sports anti -doping analysis used to test athletes urine sample for prohibited. Chemical warfare agent's detection is increased capability in homeland security and public health preparedness [2]. Food, beverage and perfume analysis are some naturally present in the raw materials and some forming during processing. Medicine is metabolic disease also known as inborn errors of metabolism are now detectable by newborn screening test [3].

Phytochemical are the chemical compound produced by plants, and it's generally to help them thrive competitors, pathogens. The plant some phytochemical have been used as poisons and other as traditional medicine. Phytochemical is generally used to identify the plants compound that are under research with effect on health and are defined as essential nutrient [4].

Phytochemical are chemical produced by plants through primary or secondary metabolism, they have biological activity in the plants host and plays a role growth or defense against competitors, pathogens. Phytochemical are regarded as research compound rather than essential nutrient because proof of their possible health effects has not been establish [5]. Phytochmeical Under research can be classified into major categories such as carotenoids and polyphenols, which include phenolic acid, flavonoids and stilbenes, flavonoids can be further divided into groups based on their similar chemical structure such as anthocyanins, flavones, flavaonones and is flavones and flanoils [6].

Pytochemists study phytochemical by first extracting and isolating compound from the origin plants, the challenging in that fields include isolating specific compounds and determining their structure, which are often complex and identifying what specific phytochemical is primarily responsible for any biological activity[7].

\subsection{Function of phytochemicals}

The phytochemical is included the most recognized compound which is essentials nutrients which are naturally contained in plant and are required for normal physiological function. The phytochemical are known phytotoxin that are more toxic to human as well as animals, some phytochemicals are antinutrients that interfere with the absorption of maximum quantity of nutrients [8].Non- digestible dietary fibers from plant food, often considered as phytochemical are the new generally regarded as nutrient groups having approved health claims for reducing the risk of some types of cancer [9].

Vegetables, grains, legumes and plant based beverages has long term of health benefits and also there are some other kind of benefits which included that is no evidence that taking dietary supplements of non- nutrients phytochemicals supplements are neither recommended by health authorities for improving health [10].

Phytochemicals in freshly harvested plants foods may be used in degraded by processing techniques, including cooking and the main cause of phytochemicals loss from cooking is thermal decomposition, in the case of carotenoids such as lycopene present in tomatoes, which is mainly stable increase in contents from cooking due to liberation from cellular membranes in the cooked foods, that cooked food processing can also free carotenoids and other phytochemicals from matrix, increasing dietary intake [11].

Plants are used medicinally in different countries, and they are the source of many potent and powerful drugs. Plants have been an important source of medicine with qualities for thousands of years. Mainly on traditional remedies such as herbs for their history, they have been used as popular folk medicines [12]. It has been shown that in vitro screening methods could provide the needed preliminary observations necessary to elect crude plant extracts with potentially useful properties for further chemical and pharmacological investigations [13].

The aim of the present study was to investigate total phenols and flavonoids content of 53 traditionally used medicinal plants of western region of India. The plants/plant parts were extracted by cold percolation method in acetone and methanol. Qualitative phyto chemical analysis was done for various phyto constituents like alkaloids, tannins, cardiac glycosides, steroids and saponins. Total phenol and flavonoid content was quantitatively estimated. Various medicinal properties have been attributed to natural herbs. Medicinal plants constitute the main source of new pharmaceuticals and healthcare products; the history of plants being used for medicinal purpose is probably as old as the history of mankind [14]. The use of medicinal plants in the industrialized societies has been traced to the extraction and development of several drugs from these plants as well as from traditionally used folk medicine. Extraction and 
characterization of several active phyto compounds from these green factories have given birth to some high activity profile drugs. The use of traditional medicine is widespread in India [15].

Phytochemical screening of plants has revealed the presence of numerous chemicals including alkaloids, tannins, flavonoids, steroids, glycosides and saponins etc. Secondary metabolites of plants serve as defense mechanisms against predation by many microorganisms, insects and herbivores Normally free radicals of different forms are generated at a low level in cells to help in the modulation of several physiological functions and are quenched by an integrated antioxidant system in the body [16]. However, if free radicals is produced in excess amount they can be destructive leading to inflammation, ischemia, lung damage and other degenerative diseases. Free radical reactions, especially with participation of oxidative radicals, have been shown to be involved in many biological processes that cause damage to lipids, proteins, membranes and nucleic acids [17].

Plants are known to produce these chemicals to protect them. While recent research demonstrates that they can also play an important role in protecting humans against diseases. Even some of these plants are in use as traditional medicine for centuries now. Most phytochemical like flavonoid, carotenoids and polyphones have anti-microbial activity and serve as a source of antimicrobial agents against pathogens [18]. In Indian system a large number of medicinal plants have been used for many centuries for treating various diseases. Medicinal plants have been as remedies for human diseases because of its chemical contents of therapeutic value. Most traditional medicines are developed from nature. Thus plants remain a major source of medicinal compounds. As of record around 20,000 plant species are in use for medicinal purposes across the globe and around $70 \%$ of them are from Indian subcontinent [19].

\subsection{Phytochemical constituents}

The chemical composition of bael is highly complex, containing many nutrients and other biologically active compounds, the proportions of which many vary considerably between strains and even among plants within the same field. Furthermore [20], the quantity of many of these constituent is significantly affected by differing growing, harvesting, processing and storage conditions that are not yet well understood [21]. The nutritional and pharmacological properties of the whole herb in its natural form, as it has been traditionally used, used result from synergistic interaction of many different active phytochemicals [22].

\section{Material and methods}

Phytochemical analysis

\subsection{Collection and processing of plant material}

The plant material of Aegle marmelos was collected in the month of June 2019 from the local area of Bangalore, Karnataka, India. The selected plant part removed and then washed under running tap water to remove dirt. The plant sample was then oven dried at $60^{\circ} \mathrm{C}$ for few days and was crushed in to powder and stored in polythene bags for future use.
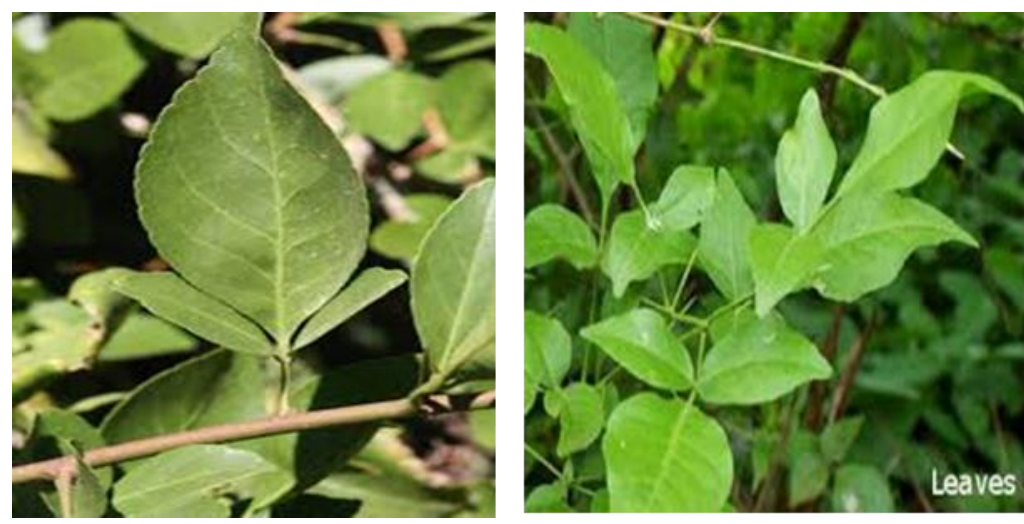

Figure 1 Plant sample leaf and stem 


\subsection{Preparation of plant extracts}

\subsubsection{Water extract}

The water extraction was carried out using classical method where grinded leaves material of 3 gm weighed using an electronic balance and was crushed in $100 \mathrm{ml}$ of sterile water. Then the mixture was boiled at 50-60 ${ }^{\circ} \mathrm{C}$ for 30 minutes on water bath and it was filtered through Whitman No.1 filter paper. Then filtrate was centrifuged at $2500 \mathrm{rpm}$ for 15 minutes and filtrate was stored in sterile bottles at $5^{\circ} \mathrm{C}$ for further use.

\subsubsection{Ethanol extract}

Samples (3 gm) were extracted with $100 \mathrm{ml}$ of $95 \%$ ethanol on water bath at $70^{\circ} \mathrm{C}$ for $2 \mathrm{hr}$. The extracted samples were centrifuged and the supernatant was transferred into $50 \mathrm{ml}$ volumetric flask. The volume adjusted to $50 \mathrm{ml}$ with $95 \%$ ethanol and the samples were stored at $-4^{\circ} \mathrm{C}$ until analysis. All water and ethanol extracts were filtered before analysis.

\subsection{Phytochemical analysis}

Qualitative analysis of extract was carried out to determine the presence of various bioactive compounds using the standard qualitative procedure.

\subsubsection{Test for alkaloids}

To $0.5 \mathrm{ml}$ of sample and $0.5 \mathrm{ml}$ of concentrated hydrochloric acid was added. Then few drops of Mayer's reagent were added, presence of green colour or white precipitate indicated the presence of alkaloids.

\subsubsection{Test for trepenoids}

To $0.5 \mathrm{ml}$ of plant sample, $2 \mathrm{ml}$ of chloroform was added and then concentrated sulphuric acid was added gently, formation of red brown colour at the interface indicated the presence of trepenoids.

\subsubsection{Test for phenols}

To $1 \mathrm{ml}$ of plant sample and $2 \mathrm{ml}$ of distilled water was added then few drops of $10 \%$ ferric chloride was added, formation of blue or green colour indicated the presence of phenols.

\subsubsection{Test for tannin}

To $0.5 \mathrm{ml}$ of plant sample and $1 \mathrm{ml}$ of $5 \%$ ferric chloride was added, formation of dark blue or greenish black is indicated the presence of tannin.

\subsubsection{Test for reducing sugar}

To $1 \mathrm{ml}$ of plant sample and $1 \mathrm{ml}$ of Fehling's A, Fehling's B was added to the sample, formation of red colour indicate the presence of reducing sugar.

\subsubsection{Test for saponins}

To $0.5 \mathrm{ml}$ of plant sample with $1 \mathrm{ml}$ of distilled water was added and shaken in a graduated cylinder for 15 min lengthwise, formation of $1 \mathrm{~cm}$ layer of foam was indicated the presence of saponins.

\subsubsection{Test for proteins}

To $1 \mathrm{ml}$ of plants sample were taken and then few drops of HNO3 was added, formation of yellow colour indicates the presence of proteins.

\subsubsection{Test for steroids}

To $0.5 \mathrm{ml}$ of plant sample with $4 \% \mathrm{NaOH}$ solution and few drops of $1 \% \mathrm{CuSo}_{4}$ solution were added, violet colour appears indicates the presence of steroids. 


\subsubsection{Test for anthocyanin}

$1 \mathrm{ml}$ of plant sample mixed with $1 \mathrm{ml}$ of chloroform and concentrated $\mathrm{H}_{2} \mathrm{SO}_{4}$ sidewise, a red colour presence at the lower chloroform layer indicates the presence of anthocyanin.

\subsubsection{Test for coumarins}

To $0.5 \mathrm{ml}$ of plant sample with $0.5 \mathrm{ml}$ of $10 \% \mathrm{NaOH}$ was added, formation of the yellow colour indicates the presence of coumarins.

\subsubsection{Test for leucoanthocyanin}

$5 \mathrm{ml}$ of isoamyl alcohol was added to $5 \mathrm{ml}$ of aqueous sample extract, upper layer appear red in colour which indicates the presence of leucoanthocyanin.

\subsubsection{Test for glycosides}

To $1 \mathrm{ml}$ of plant sample with $2 \mathrm{ml}$ of chloroform and $10 \%$ of ammonia solution was added, formation of pink colour indicates the presence of glycosides.

\subsubsection{Test for carbohydrate}

To $0.5 \mathrm{ml}$ of plant sample with $1 \mathrm{ml}$ of Molisch's reagent and few drops of concentrated sulphuric acid were added, presence of purple colour or reddish colour indicated the presence of carbohydrate.

\section{GC-MS analysis}

\subsection{Preparation of extract}

The plant material of Aegle marmelos was collected from wild area, leaf should kept in hot air oven few day for properly dried, after that the dried leaf is pulverized to powder using mechanical grinder, then the required amount plant powder of Aegle marmelos was weighed and transferred to flask, treated with methanol until the powder was fully immersed, incubated overnight and filtrate through Whatmaan filter paper along with sodium sulfate to remove the sediments and trace of water in the filter paper, before filtering, the filter paper along with sodium sulfate was wetted with alcohol. The filtrate is then concentrated to $1 \mathrm{ml}$ by bubbling nitrogen gas into the solution. The extract contains both polar and non-polar components of the plant material and $2 \mathrm{ml}$ of the sample of the solution was employed in GC-MS for analysis of different compounds.

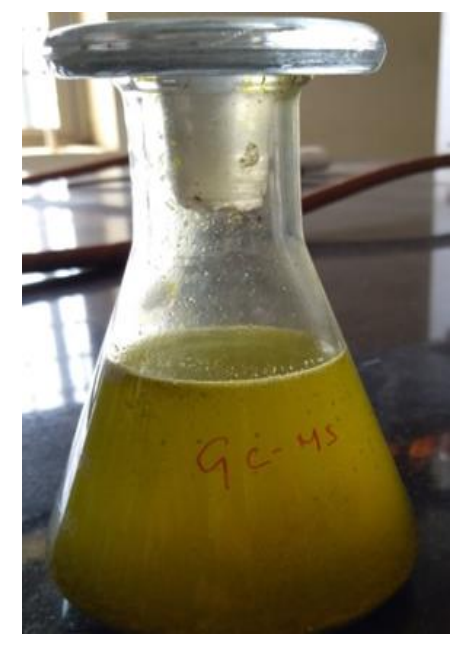

Figure 2 GCMS plant extract preparation

\section{Antimicrobial activity of plant extracts}

Antimicrobial tests for the leaves stem and roots of the studied plants were carried out against the pure cultures of pseudomonas and Escherichia coli. Bacteria were cultured overnight at $37^{\circ} \mathrm{C}$ for 72 hour. Nutrient agar (20 ml) was 
dispensed into sterile universal bottles. These were then inoculated, mixed gently and poured into sterile petridishes. After setting a number 3-cup borer $(6 \mathrm{~mm})$ diameter was properly sterilized by flaming and used to make 3 uniform well in each petridishes. A drop of molten nutrient agar was used to seal the base of each cup. The wells were filled with 50 of the extract concentration of $100 \mathrm{~g} / \mathrm{ml}$ and allow for diffuse $\left(45\right.$ minutes). The plates were incubated at $37^{\circ} \mathrm{C}$ for 24 hours for bacteria. The zone of inhibition for the extract /fractions that showed antimicrobial activity was measured with antibiotic zone in $\mathrm{mm}$.

\section{Results}

\subsection{Phytochemical characterization}

Table 1 Phytochemical screening results

\begin{tabular}{lcc}
\hline Test name & leaves & Stem \\
\hline Alkaloids & + & + \\
Trepenoids & + & - \\
Phenol & - & - \\
Tannin & + & - \\
Reducing sugar & - & + \\
Saponin & + & + \\
Proteins & - & + \\
Steroids & + & + \\
Anthocyanin & - & - \\
Coumarin & + & - \\
Leucoanthocyanin & + & + \\
Glycosides & - & - \\
Carbohydrate & + & - \\
\hline
\end{tabular}

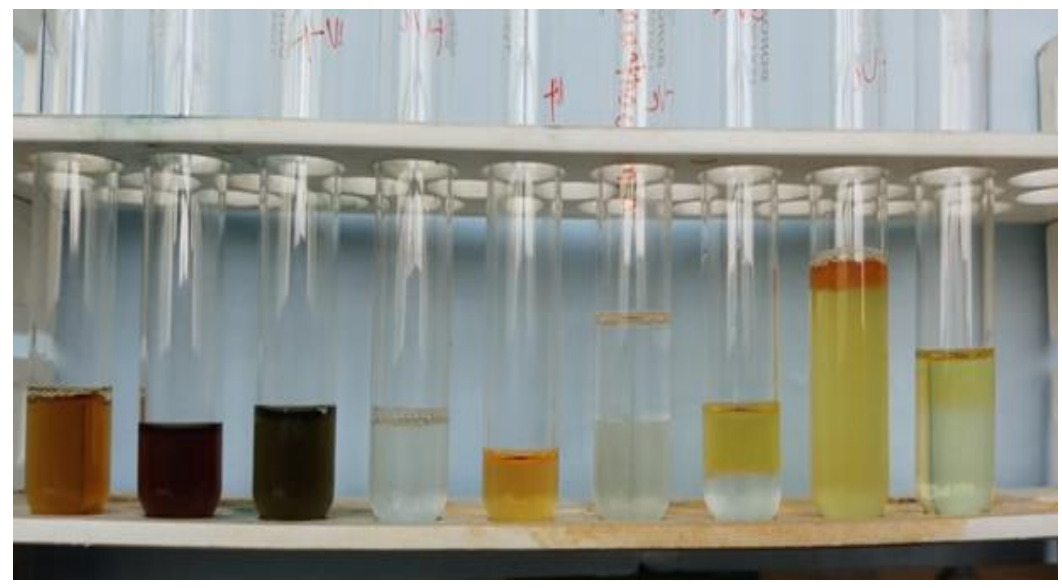

Figure 3 Phytochemical analysis results 


\subsection{GCMS analysis results}

Table 2 GCMS analysis results

\begin{tabular}{|c|c|c|c|c|c|c|c|}
\hline $\begin{array}{l}\text { Sr. } \\
\text { No }\end{array}$ & Name & $\begin{array}{l}\text { R.T. } \\
\text { (min:sec) }\end{array}$ & Similarity & Area \% & Formula & Area & $\begin{array}{l}\text { Exact } \\
\text { Mass }\end{array}$ \\
\hline 1 & Unknown 1 & 03:16.1 & 680 & 0.32 & $\mathrm{C}_{6} \mathrm{H}_{14} \mathrm{O}_{5}$ & 12175118.00 & 166.08 \\
\hline 2 & $\begin{array}{l}\text { Acetic acid, dichloro-, } \\
\text { methyl ester }\end{array}$ & $04: 22.9$ & 763 & 0.29 & $\mathrm{C}_{3} \mathrm{H}_{4} \mathrm{Cl}_{2} \mathrm{O}$ & 11133589.00 & 141.96 \\
\hline 3 & $\begin{array}{l}\text { Benzene, 1,3-bis(1,1- } \\
\text { dimethylethyl)- }\end{array}$ & $04: 54.1$ & 932 & 0.20 & $\mathrm{C}_{14} \mathrm{H}_{22}$ & 7756004.00 & 190.17 \\
\hline 4 & 11-Methyldodecanol & $05: 24.3$ & 873 & 0.32 & $\mathrm{C}_{13} \mathrm{H}_{28} \mathrm{O}$ & 12164032.00 & 200.21 \\
\hline 5 & 11-Methyldodecanol & $05: 28.5$ & 864 & 0.35 & $\mathrm{C}_{13} \mathrm{H}_{28} \mathrm{O}$ & 13342022.00 & 200.21 \\
\hline 6 & Tridecane & $06: 07.7$ & 961 & 0.14 & $\mathrm{C}_{13} \mathrm{H}_{28}$ & 5391644.00 & 184.22 \\
\hline 7 & $\begin{array}{l}\text { 1-Ethyl-4,4-dimethyl-2,5- } \\
\text { dioxoimidazolidine }\end{array}$ & $06: 13.5$ & 759 & 0.00 & $\begin{array}{l}\mathrm{C}_{7} \mathrm{H}_{12} \mathrm{~N}_{2} \mathrm{O} \\
2\end{array}$ & 0.00 & 156.09 \\
\hline 8 & $\begin{array}{l}\text { Decane, } \\
\text { tetramethyl- }\end{array}$ & $06: 29.1$ & 942 & 0.02 & $\mathrm{C}_{14} \mathrm{H}_{30}$ & 833058.00 & 198.23 \\
\hline 9 & Heneicosane & $06: 34.4$ & 904 & 0.24 & $\mathrm{C}_{21} \mathrm{H}_{44}$ & 9251481.00 & 296.34 \\
\hline 10 & $\begin{array}{l}\text { Heptadecane, } \\
\text { dimethyl- }\end{array}$ & $06: 39.0$ & 962 & 0.21 & $\mathrm{C}_{19} \mathrm{H}_{40}$ & 8203625.00 & 268.31 \\
\hline 11 & 1-Octanol, 2-butyl- & $06: 42.4$ & 807 & 0.03 & $\mathrm{C}_{12} \mathrm{H}_{26} \mathrm{O}$ & 1102525.00 & 186.20 \\
\hline 12 & $\begin{array}{l}\text { Heptadecane, } \\
\text { dimethyl- }\end{array}$ & $06: 43.2$ & 960 & 0.20 & $\mathrm{C}_{19} \mathrm{H}_{40}$ & 7780891.00 & 268.31 \\
\hline 13 & $\begin{array}{l}\text { Heptadecane, } \\
\text { dimethyl- }\end{array}$ & $06: 48.1$ & 950 & 0.22 & $\mathrm{C}_{19} \mathrm{H}_{40}$ & 8396649.00 & 268.31 \\
\hline
\end{tabular}

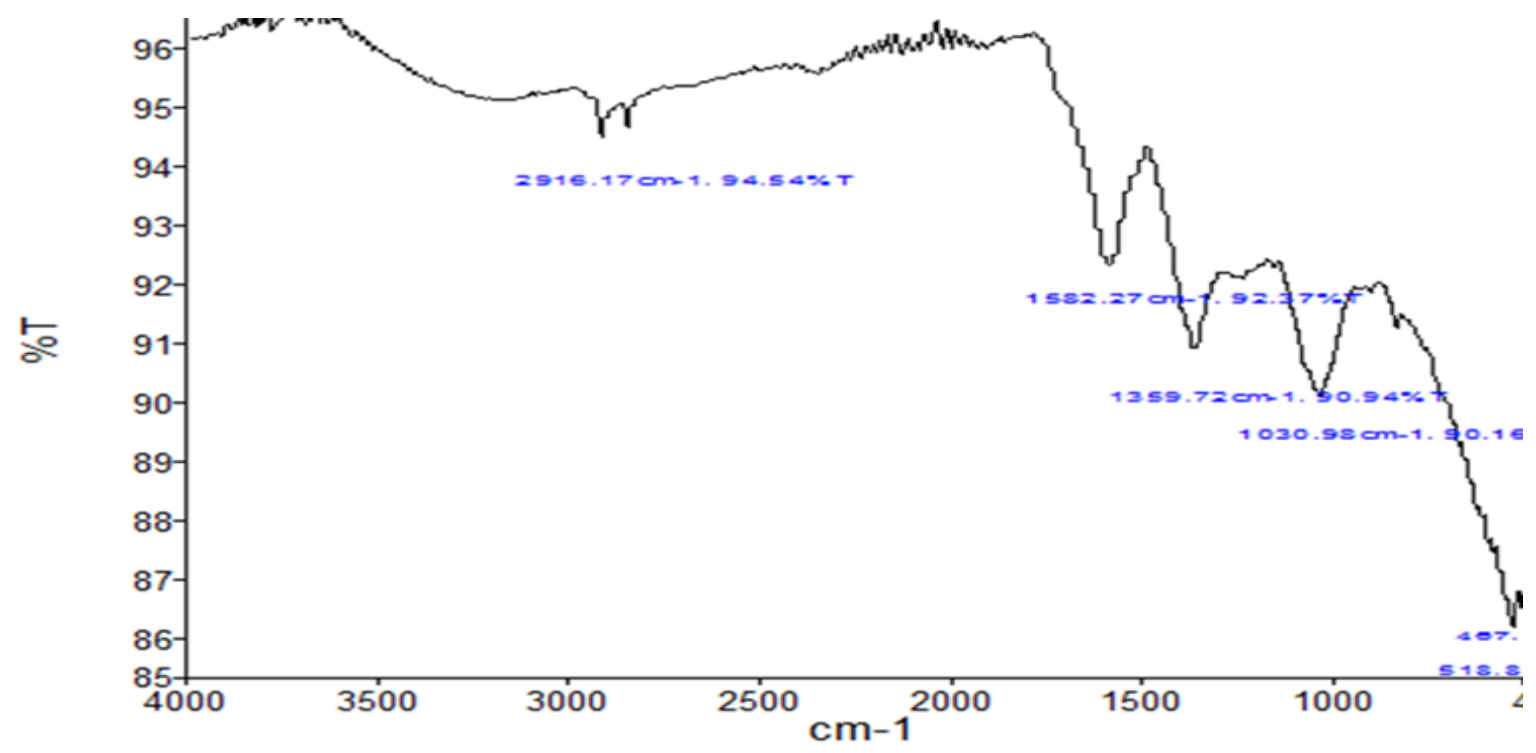

Figure 4 GCMS analysis graph 


\subsection{Antimicrobial activity test}

Table 3 Antimicrobial activity tests

\begin{tabular}{|c|c|c|c|c|c|c|c|}
\hline \multirow{3}{*}{$\begin{array}{l}\text { Plants sample } \\
\text { Aegle marmelos }\end{array}$} & \multirow{2}{*}{$\begin{array}{l}\text { Organism } \\
\text { Pseudomonas }\end{array}$} & \multirow{2}{*}{$\begin{array}{l}\text { Media } \\
\begin{array}{l}\text { Nutrient } \\
\text { media }\end{array}\end{array}$} & \multirow{2}{*}{$\begin{array}{l}\text { Extract } \\
\text { Stem }\end{array}$} & \multicolumn{2}{|c|}{$\begin{array}{l}24 \text { hours } \\
\text { inhibition }\end{array}$} & $\begin{array}{l}48 \text { hours } \\
\text { inhibition }\end{array}$ & $\begin{array}{l}72 \text { hours } \\
\text { inhibition }\end{array}$ \\
\hline & & & & $\begin{array}{l}\text { Present } \\
\mathrm{mm}\end{array}$ & 3 & $\begin{array}{l}\text { Present } 2.4 \\
\mathrm{~mm}\end{array}$ & $\begin{array}{l}\text { Present } 4.1 \\
\mathrm{~mm}\end{array}$ \\
\hline & E. coli & $\begin{array}{l}\text { Nutrient } \\
\text { media }\end{array}$ & Leaves & $\begin{array}{l}\text { Present } \\
\mathrm{mm}\end{array}$ & 2 & $\begin{array}{l}\text { Present } 4.2 \\
\mathrm{~mm}\end{array}$ & $\begin{array}{l}\text { Present } 2.5 \\
\mathrm{~mm}\end{array}$ \\
\hline
\end{tabular}

\section{Conclusion}

Aegle marmelos is a popular home remedy for many ailments such as wound, bronchitis, liver diseases, catarrhal fever, otalgia, lumbago, hiccough, ophthalmia, gastric disorders, genitourinary disorders, skin diseases, various forms of poisoning and psychosomatic stress disorders1-2. It has also aromatic, stomachic, carminative, demulcent, diaphoretic, diuretic, expectorant, alexiteric, vermifuge and febrifuge properties. Phytochemical screening leaves extracts of herbs A. marmelos one medicinally important tree had revealed the presence flavonoids, alkaloids, terpenoids, phenol and tanins saponins, steroids, coumarin Glycosides by positive reaction with the respective test reagent.

\section{Compliance with ethical standards}

\section{Acknowledgments}

We gratefully acknowledge to our guide Deepthikiran for providing the finical and proper guide for this research paper. And also thanks to our head of department to allow to do all experiment.

\section{Disclosure of conflict of interest}

The authors declare that there are no conflicts of interest.

\section{References}

[1] Anker JN, Hall WP, Lyandres 0, Shah NC, Zhao J and Van Duyne RP. (2008). Biosensing with plasmonic nanosensors. Nature Materials, 7, 442-453.

[2] Byrappa K and Adschiri T. (2007). Hydrothermal technology for nanotechnology. Progressin Crystal Growth and Characterization of Materials, 53, 117-166.

[3] Chandran SP, Chaudhary M, Pasricha R, Ahmad A and Sastry M. (2006). Synthesis of gold nanotriangles and silver nanoparticles using Aloe vera plant extract. Biotechnology Progress, 22, 577-583.

[4] Cho KH, Park JE, Osaka T and Park SG. (2005). The study of antimicrobial activity and preservative effects of nanosilver ingredient. Electrochimica Acta. 51, 956-960.

[5] Chudasama B, Vala AK, Andhariya N, Mehta R and Upadhyay R. (2010). Highly bacterial resistant silver nanoparticles: synthesis and antibacterial activities. Journal of Nanoparticle Research, 12, 1677-1685.

[6] Cui L, Chen P, Chen S, Yuan Z, Yu C, Ren B and Zhang K. (2013) .In situ study of the antibacterial activity and mechanism of action of silver nanoparticles by surface-enhanced Raman spectroscopy. Analytical Chemistry, 85, 5436-5443.

[7] Emaga TH, Robert C, Ronkart SN, Wathelet B and Paquot M. (2008). Dietary fiber components and pectin chemical features of peels during ripening in banana and plantain varieties. Bioresource Technology, 99, 43464354. 
[8] Feng Q, Wu J, Chen G, Cui F, Kim T and Kim J. (2000). A mechanistic study of the antibacterial effect of silver ions on Escherichia coli and Staphylococcus aureus. Journal of Biomedical Materials Research, 52, 662-668.

[9] Griffin SG, Wyllie SG, Markham JL and Leach DN. (1999). The role of structure and molecular properties of terpenoids in determining their antimicrobial activity. Flavour and Fragrance Journal, 14, 322-332.

[10] Hajipour MJ, Fromm KM, Ashkarran AA, De Aberasturi DJ, De Larramendi IR, Rojo T, Serpooshan V, Parak WJ and Mahmoudi M. (2012) . Antibacterial properties of nanoparticles. Trends in Biotechnology, 30, 499-511.

[11] Lee G-J, Shin S-I, Kim Y-C and Oh S-G. (2004). Preparation of silver nanorods through the control of temperature and $\mathrm{pH}$ of reaction medium. Materials Chemistry and Physics, 84, 197204.

[12] Lee K-S and El-Sayed MA. (2006). Gold and silver nanoparticles in sensing and imaging: sensitivity of plasmon response to size, shape, and metal composition. The Journal of Physical Chemistry B, 110, 19220-19225.

[13] Liu J, Sonshine DA, Shervani S and Hurt RH. (2010). Controlled release of biologically active silver from nanosilver surfaces. ACS Nano, 4, 6903-6913.

[14] Liu Z, Wang Y, Zu Y, Fu Y, Li N, Guo N, Liu R and Zhang Y. (2014). Synthesis of polyethylenimine (PEI) functionalized silver nanoparticles by a hydrothermal method and their antibacterial activity study. Materials Science and Engineering: C, 42, 31-37.

[15] Liu Z, Xing Z, Zu Y, Tan S, Zhao L, Zhou Z and Sun T. (2012). Synthesis and characterization of L-histidine capped silver nanoparticles. Materials Science and Engineering: C, 32, 811-816.

[16] Livermore DM. (2002). Multiple mechanisms of antimicrobial resistance in Pseudomonas aeruginosa: our worst nightmare? Clinical Infectious Diseases, 34(5), 634-640.

[17] Morones JR, Elechiguerra JL, Camacho A, Holt K, Kouri JB, Ramirez JT and Yacaman MJ. (2005). The bactericidal effect of silver nanoparticles. Nanotechnology, 16, 23462353.

[18] Nabikhan A, Kandasamy K, Raj A and Alikunhi NM. (2010). Synthesis of antimicrobial silver nanoparticles by callus and leaf extracts from saltmarsh plant, Sesuvium portulacastrum. L. Colloids and Surfaces B: Biointerfaces, 79, 488-493.

[19] OttoM. (2009). Staphylococcus epidermidis-the "accidental" pathogen. Nature Reviews Microbiology, 7(8), 555-567.

[20] Pal S, Tak YK and Song JM. (2007). Does the antibacterial activity of silver nanoparticles depend on the shape of the nanoparticle? A study of the gram-negative bacterium Escherichia coli. Applied and Environmental Microbiology, 73, 1712-1720.

[21] DeLeo FR, Renee J, McCormick S, Nakamura M, Weiss JP and Nauseef WM. (1998).Neutrophils exposed to bacterial lipopolysaccharide up regulate NADPH oxidase assembly. Journal of clinical investigation.

[22] Monga J, Sharma M, Tailor N and Ganesh N. (2011). Antimelanoma and radioprotective activity of alcoholic aqueous extract of different species of Ocimum in C57BL mice. Pharmaceutical biology, 49(4), 428-436.

\section{How to cite this article}

Sahu AK, Kar BR, Deepthi K, Pallath KS, Dakni SJ, Samal P, Niharika NS, Swetha T, Sneha T, A. Anthony SP and HG Varshini R. (2019). Gas chromatography and mass spectroscopy analysis and phytochemical characterization of Aegle marmelos (Bael) leaf, Stem and its screening of antimicrobial activity. GSC Biological and Pharmaceutical Sciences, $8(3), 122-130$. 